\title{
Penyebab dan Upaya yang Dilakukan Para Pemerintah Dunia Saat Krisis Global 2008
}

\author{
Hasmiah Herawati ${ }^{1}$, Mukarramah Gustan ${ }^{2}$ \\ ${ }^{1,2}$ Fakultas Tarbiyah, IAIN Parepare, Parepare, 91131, Indonesia \\ *email: hasmiahherawati@iainpare.ac.id
}

\begin{abstract}
Abstrak
Di era globalisasi ini semakin terintegrasinya perekonomian yang sejalan dengan teknologi informasi. Dalam kurun waktu yang sangat singkat, krisis keuangan yang terjadi di Amerika Serikat dengan sangat cepat merambak ke negara-negara lain sehingga berkembang menjadi masalah yang cukup serius yang menimbulkan pengaruh keuangan ekonomi. Krisis 2008 ini merupakan krisis keuangan global yang sangat buruk dalam kurun waktu 80 tahun terakhir. Krisis yang awalnya dialami karena subprime mortgage di Amerika Serikat ternyata berpengaruh pada dunia internasional. Oleh karena itu, para pemimpin negara mengupayakan agar krisis dapat diminimalisir dengan diadakannya rapat yang dihadiri oleh G-20. G-20 ini merupakan para kelompok perekonomian besar di dunia.
\end{abstract}

Kata kunci: penyebab, upaya, pemerintah, krisis global

\begin{abstract}
Abstact
In this globalization era, economic integration is increasingly in line with information technology. In a very short period of time, the financial crisis that occurred in the United States quickly spread to other countries so that it developed into a problem that was quite serious which had the effect of economic finance. This 2008 crisis is a very bad global financial crisis in the past 80 years. The crisis that was initially experienced due to subprime mortgages in the United States turned out to affect the international world. Therefore, the country's leaders strive to minimize the crisis by holding a meeting attended by the G-20. The G-20 is a major economic group in the world.
\end{abstract}

Keywords: causes, efforts, government, global crisis

\section{Pendahuluan}

Sejarah mencatat bahwa serangkaian krisis keuangan yang dialami berbagai negara secara destruktif telah merusak sendi-sendi perekonomian negara-negara tersebut. Sejumlah negara dalam tenggang waktu berbeda mengalami krisis keuangan sejak pertengahan tahun 1990-an hingga tahun 2001. Krisis pertama kali terjadi di Meksiko pada tahun 1973-1982. Krisis ini disebabkan dengan adanya permasalahan fiskal dan moneter (Kaminsky, 2003). Flood dan Garber (1984) dan Krugman (2007) menyatakan bahwa krisis generasi pertama disebabkan oleh ketidakseimbangan kondisi makro ekonomi. Bukan hanya itu, krisis mata uang juga dapat terjadi karena adanya defisit anggaran pemerintah dan sistem nilai tukar tetap (Nezky, 2013). 
Sementara negara- negara di kawasan Asia termasuk Indonesia mengalami krisis yang cukup terbilang parah di tahun yang juga bersamaan bangkrutnya beberapa perusahaan lembaga keuangan internasional di tahun 1997 dan 1998 yang pada saat itu kualitasnya tampaknya tidak diragukan lagi contohnya seperti Lehman Brothers, AIG, Fannie Mae, Freddie Mac pada tahun 2008. Kondisi pada saat itu ternyata semakin memburuk, meluas, bahkan berkepanjangan karena tidak hanya dirasakan oleh perekonomian Amerika tetapi juga dirasakan di berbagai dunia, baik itu di negara maju sekalipun maupun negara bekembang, semuanya mengalami kebangkrutan serta jatuhnya harga harga saham.

Imbas krisis keuangan di Amerika pada akhirnya juga dirasakan oleh Indonesia. Keyakinan yang tinggi dari pemerintah Indonesia bahwa krisis di Amerika tidak akan berimbas kepada perekonomian Indonesia karena memiliki fundamental yang kuat ternyata tidak terbukti. Dalam beberapa tahun terakhir imbas krisis Amerika sangat kuat dirasakan oleh bangsa Indonesia dan terlihat dari beberapa indikator sebagai berikut. Pada saat itu nilai tukar rupiah terhadap dollar US terus merosot bahkan pemerintah sulit mencari pinjaman karena indeks harga saham di BEI sangat menurun secara drastis. Dari berbagai hal tersebut, artikel ini membahas mengenai penyebab terjadinya krisis keuangan global dan kondisi perekonomian Indonesia saat krisis global 2008.

\section{Pembahasan}

\section{Penyebab Krisis Keuangan Global}

Kriris memiliki arti yang cukup luas, salah satu pengertian krisis menurut Harberler yaitu "Penyimpangan kegiatan ekonomi yang menyolok dan merupakan titik awal gerak kegiatan ekonomi yang menurun/down-turn atau the upper turning point" (Estey, 1960). Begitu juga dengan Mitchell mengartikan krisis adalah suatu kondisi ekonomi yang sudah mengalami atau dengan kata lain agak resesi (rather than recession) (Teguh, 2009). Sedangkan Menurut ahli ekonomi secara sederhana krisis itu terjadi karena harga-harga melonjak tinggi dari sebelumnya dan tidak adanya lagi kepercayaan masyarakat kepada pemerintah, terkhususnya masalah finansial dimana masyarakat tersebut tidak mau lagi menyimpan uang di bank (Nur 2020).

Maka dari itu menurut (Tarmidi, 1998) langkah yang harus segera mungkin dilakukan untuk menanggulangi suatu krisis ekonomi ini adalah pemecahan masalah utang swasta luar negeri, melakukan pembenahan kapasitas perbankan nasional dan tak lupa mengembalikan harapan rakyat di dalam negeri maupun di luar negeri dalam hal kapasitas ekonomi Indonesia yang dapat menstabilkan nilai tukar rupiah di tingkat yang sesungguhnya dan yang juga sangat relevan yaitu menstabilkan kembali sosial dan politik.

Lain halnya dengan (Nezky, 2013) yang mengaitkan suatu krisis terjadi karena sejumlah hal-hal yang penting. Pertama, karena adanya kerugian di pasar keuangan, kedua, posisi dimana suatu lembaga moneter kehilangan setengah kekayaannya, ketiga, ketakutan perbankan akan lenyapnya default kredit maupun resesi, keempat jatuhnya nilai mata uang dan bursa saham. Jadi pada intinya efek perusahaan yang telah terdaftar sangat berhubungan dengan pembelian maupun penjualan yang menjadi akar utama penanaman modal eksternal perusahaan maupun pemerintah.

Secara umum beberapa peneliti mengkategorikan menjadi beberapa jenis krisis: sebut saja (Kaminsky, 2003) mengatakan bahwa krisis yang pertama kali terjadi di Meksiko pada tahun tahun 1973-1982. Kemudian Flood dan Garber (1984) dan 
Krugman (2007) kemudian melanjutkan krisis generasi pertama bukan hanya permasalahan krisis moneter dan fiskal tetapi juga lemahnya kondisi makro ekonomi. Krisis kedua atau biasa disebut dengan Second Generation Crisis awalnya disampaikan oleh Obstfeld (1994) serta Cole dan Keho (1996) menyebutnya krisis kedua ini terjadi di Eropa pada tahun 1992 hingga 1993 yang melanda sistem keuangan karena pemerintah ingin menerapkan sistem nilai tukar terhadap ekspansi moneter. Sementara krisis generasi ketiga Menurut Krugman adalah gabungan krisis generasi pertama dan kedua sehingga disebutnya dengan krisis kembar (Nezky, 2013).

Sejak era globalisasi, krisis keuangan menjadi lebih sering terjadi daripada sebelumnya. Kemajuan dalam hal teknologi informasi menjadi salah satu alasan terjadinya krisis karena dapat memperbesar dan mempercepat penyebaran informasi dari negara bahkan ke daerah sekalipun. Dalam dua puluh tahun terakhir sudah terjadi krisis keuangan yang terbilang besar di beberapa negara yaitu yang pertama Krisis Keuangan Asia Timur 1997 dan kedua Krisis Keuangan Global 2008. Jika dikaitkan dengan teknlogi informasi dalam hal ini (Timur et al., 2012) menyatakan bahwa sistem keuangan dunia dapat menjalar lebih mudah dan lebih cepat karena didukung oleh perkembangan teknologi informasi yang telah memperkuat integrasi keuangan perekonomian dengan hal ini sangat berkaitan dengan antarnegara di dunia.

Percaya atau tidak percaya krisis keuangan ini akan terulang lagi karena seperti pernyataan Grant (1998), seorang pengamat pasar modal yang melakukan riset dalam sejarah keuangan menulis dalam bukunya "The Trouble with Prosperity", bahwa keuangan memiliki siklus masa makmur yang kemudian selalu akan diikuti dengan masa suram, atau sebaliknya.(Njoo, 2008)

Konsekuensi dari krisis keuangan selalu dikaitkan dengan indikator makro ekonomi, khususnya pertumbuhan ekonomi. Hal ini membuktikan bahwa sumber krisis dapat bervariasi seperti halnya Asia Timur, pertumbuhan ekonomi Asia Timur jatuh dari wilayah dengan pertumbuhan tercepat di dunia menjadi wilayah yang beberapa negara anggotanya mencatat pertumbuhan pendapatan yang negatif pada tahun 1998 seperti Indonesia, Malaysia, Singapura, Korea Selatan, Filipina dan Thailand (Timur et al., 2012).

Hal tersebut juga dikemukakan oleh (Faiz, 2010) bahwa makro ekonomi sudah seringkali menimbulkan terjadinya penghambatan kredit yang imbasnya pada krisis yang lebih rumit. Menurutnya wujud dari krisis yang terjadi sangat berformasi, mulai dari runtuhnya pasar saham dan nilai mata uang yang mengalami kesulitan sampai banyak nasabah yang menyimpan uangnya kemudian nasabah tersebut memutuskan untuk menarik uangnya kembali, hal itu biasa disebut dengan banking rush, bukan hanya itu krisis ini juga menyebabkan pemerintah mengalami kegagalan pelunasan utang.

Namun Krisis Asia Timur pada tahun 1997 menunjukkan angka yang cukup besar dibanding dummy Krisis Keuangan Global pada tahun 2008. Hal ini searah dengan keinginan sebab Krisis Asia Timur 1997 terjadi di wilayah Asia Timur dan merupakan hasil dari akar internal wilayah tersebut, termasuk yang pertama kurangnya kredibilitas kebijakan dan kedua infrastruktur keuangan yang tidak terpenuhi sehingga secara bersamaan terjadi proses pencabutan (Timur et al., 2012). (Nezky, 2013) menyebut krisis Asia Timur 1997 dengan sebutan krisis kembar. Krisis kembar ini disebabkan karena kondisi perbankan mengalami penyusutan dan tingginya nilai tukar. 
(Nur, 2020) menyimpulkan bahwa krisis ekonomi tidak hanya satu faktor saja, bahkan bisa saja dua faktor yaitu faktor internal maupun eksternal. Faktor internalnya yaitu pertumbuhan yang merupakan kunci utama ekonomi makro, kedua struktur ekonomi yang tidak seimbang, ketiga perdagangan luar negeri masih lemah dalam hal mengembangkan ekspor. Adapun faktor eksternalnya salah satunya yaitu adanya ketidakseimbangan global di negara-negara maju dan pasar keuangan global.

Penyebab krisis juga dikemukakan oleh (Hidayat, 2008), ia mengatakan bahwa di tahun 2008 resesi ekonomi berasal dari melonjaknya harga minyak dunia. Hal itu tentunya akan mendorong tingginya harga bahan pangan, mengingat keduanya sangat berpengaruh sebagai energi alternatif pengganti minyak maka diubahlah bahan pangan menjadi etanol dan biosel. Tidak jauh berbeda dengan (Teguh, 2009) yang mengatakan Amerika Serikat telah masuk pada tahap bahaya resesi, yang menjadi dasar pokoknya yaitu (1) Keuangan yang rapuh, (2) Pasar tetap lemah, (3) Adanya ketidakjelasan bankbank besar terkena dampak krisis kredit, (4) hingga tingginya harga minyak, dan (5) Lemahnya daya beli konsumen.

Krisis keuangan global yang terjadi saat ini sangat berkaitan erat dengan kondisi perekonomian Amerika yang memburuk. Krisis keuangan yang semula hanya dialami oleh Amerika kini merambak hingga ke negara-negara lainnya yang membuat ekonomi melambat secara global. Hal ini tentunya menjadi masalah yang serius. Hambatan yang terjadi pada negara adikuasa tersebut dipastikan telah memberikan dampak yang sangat besar terhadap perekonomian dunia. Gejolak perekonomian yang terjadi di Amerika Serikat telah mempengaruhi stabilitas ekonomi global di beberapa kawasan. Keterbukaan ekonomi antar negara memungkinkan terjadinya resesi di suatu negara untuk mengarah dan mempengaruhi negara lainnya.

(Njoo, 2008) berpendapat bahwa krisis keuangan global merupakan "made in America" dalam arti Amerika telah mengekspor surat-surat berharga berdasarkan hutang nasabah dan mortgage dari aset aset yang dianggap terlalu tinggi dan pada akhirnya menimbulkan kebangkrutan sistem keuangan dunia. Seperti yang diketahui jika seseorang mengkredit barang-barang tentunya memiliki bunga. Begitupun dengan utang hipotek ini juga menghasilkan biaya bunga. Dalam artian peminjam tidak hanya bertanggung jawab membayar utang pokoknya tetapi juga harus membayar bunganya.

Seperti yang diketahui PDB Amerika Serikat itu berada pada angka US \$13,1 Triliun, angka tersebut cukup besar setara 20\% dari PDB dunia pada tahun 2007. Namun hal itu ternyata tidak bisa menopang ekonominya sehingga dampak krisis kredit dalam pasar mortgage senilai US \$1,8 Triliun. Negara super power itu dihadapkan pada penurunan ekonomi yang menghadapi para pesaing baru China dan India. Namun hal itu tetap saja masih berpengaruh kuat pada percaturan ekonomi dunia (Teguh, 2009).

(Hidayat, 2008) menyatakan bahwa pada tahun 2006-2007, terjadilah kenaikan suku bunga kredit, dari sanalah awal mula permasalahan kredit perumahan tersebut menyebar dimana kredit perumahan itu disekuritisasi dan banyak dipegang bahkan dibeli oleh lembaga finansial dan pada akhirnya lembaga keuangan tersebut banyak kehilangan nilai asetnya akibat sekuritisasi aset tersebut turun harganya, dampaknya adalah ambruknya sisi permodalan dari banyak perbankan dan pemerintahan Amerika Serikat memberitahu lembaga keuangannya untuk mengetatkan kredit di seluruh dunia.

Kemudian pada tahun 2008 tepatnya dibulan Agustus gelombang ekonomi kembali meledak di pasar perumahan Amerika Serikat sebagai akhir dari subprime 
mortgage yang terjadi tahun lalu. Ancaman dari krisis ini adalah depresi ekonomi yang universal (Hadi, 2008). Sebagaimana yang dinyatakan oleh (Hidayat, 2008) bahwa subprime mortgage ini terjadi karena dalam beberapa tahun terkahir cukup banyak kredit perumahan di Amerika Serikat yang sangat beresiko, dalam artian kredit perumahan tersebut diberikan kepada rumah tangga yang berpenghasilan rendah dan juga tanpa uang muka yang lebih parahnya lagi rumah tangga tersebut mempunyai catatan kredit bermasalah.

Hal serupa juga dikemukakan oleh (Teguh, 2009) bahawa pada pertengahan 2007 kian memanas akibat subprime mortgage ini yang menghancurkan bursa. Bahkan satu per satu perusahaan besar berjatuhan seperti: Bear Stern, Morgan Stanley, Citigroup, bahkan General Motor pun ikut jatuh. Subprime mortgage penyebab krisis pasar uang antar bank menelan banyak korban sampai Eropa dan Jepang, sampai-sampai Bank dan perusahaan sekuriti telah menghapus buku aset dan per 1 April 2008 US \$ 232 miliar mengalami kerugian.

Bangkrutnya Northern Rock di Inggris, Bear Sterns di Amerika serikat (AS) memicu gelapnya perekonomian dunia, efek dari depresi ini diperkirakan akan menghentikan lapangan kerja dan pertumbuhan perekonomian selama kurang lebih satu dekade, bahkan Perusahaan investasi lain seperti Merril Lynch yang bertahun-tahun sempat menjadi raja, Wall Street pun kini meminta untuk segera diambil alih oleh saingannya sendiri yaitu Bank of America. Bahkan AIG, salah satu perusahaan asuransi terbesar ini memohon agar dana darurat disuntikkan sebanyak 40 bilyun dollar dari pemerintah Amerika Serikat, hal ini dilakukan agar menghindari kebangkrutan total. Beberapa peristiwa ini dirangkum oleh majalah Wall Street Journal dengan katakata," Sistem keuangan Amerika serikat terguncang hingga ke pusarnya". Sampai Alan Greenspan, mantan kepala Bank Sentral Amerika Serikat, menyebut krisis keuangan dunia saat ini sebagai kejadian yang terjadi sekali dalam 100 tahun. Bangkrutnya lehman brothers tercatat sebagai kebangkrutan terbesar dalam sejarah korporasi AS. Perusahaan asuransi terbesar, AIG, juga di ambang kehancuran (Hadi, 2008)

Untuk mencari solusi dari krisis global ini (Hidayat, 2008) menjelaskan bahwa di National Building Museum yang dibangun sejak 1882 sampai 1887 dilangsungkan sebuah pertemuan pada tanggal 15 November yang dihadiri dari beberapa kepala negara G-20. Negara-negara yang tergabung dalam G-20 merupakan kelompok perekonomian besar yang beranggotakan 19 negara yaitu Argentina, Australia, Brasil, Kanada, Prancis, Tiongkok, Jerman, India, Italia, Jepang, Meksiko, Rusia, Arab Saudi, Afrika Selatan, Korea Selatan, Turki, Britania Raya, Amerika Serika, ditambah dengan Uni Eropa. Jadi secara resmi G-20 (Group of twenty) dibuat secara sistematis untuk memobilisasi kekuatan kekuatan ekonomi maju dan berkembang dan juga membicarakan isu-isu terkait perekonomian internasional. Indonesia merupakan satu satunya negara Asia di kawasan tenggara yang masuk dalam anggota G-20 alasannya dikarenakan faktor ekonomi Indonesia menempati 20 besar dalam kekuatan ekonomi dunia dan juga Indonesia merupakan penduduk terbesar ke empat setelah Amerika Serikat, China dan juga India.

Adapun perundingan yang dibahas yaitu 1) perundingan perdagangan, dimana tidak hambatan perdaganga tidak dinaikkan dalam 1 tahun kedepan dan mengadakan kembali perundingan ini di akhir tahun. 2) institusi keuangan global, ada dua jenis langkah yang diambil disini. Pertama, langkah jangka pendek yaitu dilakukakannya dengan cepat untuk memperluas keanggotaan finansial stability forum(FSF) yang 
mengikutsertakan negara berkembang serta berkontribusi dalam negara ekonomi berkembang sehingga mendapatkan akses keuangan dan memriksa IMF, Bank Dunia, dan Bank Pengembangan Multilateral mendapatkan dana yang cukup. Sedangkan langkah jangka menengah yang harus dilaksanakan adalah melakukan perubahan secara menyeluruh kepada IMF dan Bank Dunia kemudian menyerahkan negara berkembang untuk menyuarakan haknya yang lebih besar; serta peran pengawasan IMF lebih ditingkatkan lagi dalam menyampaikan saran dalam persoalan ekonomi makro dan stabilitas keuangan (Hidayat, 2008)

Krisis global yang menghantam negara adidaya ditahun 2008 tidak selamanya disebut petaka karena hal ini bagaikan dua sisi mata pisau, dimana terdapat peluang (opportunity) dan juga tantangan (threat). Mengapa demikian? Karena poin positifnya adalah harga minyak cenderung turun sehingga mengurangi dampak inflasi dan negaranegara industri juga berlomba-lomba menyelenggarakan cost cutting agar memperkecil pengeluaran. Namun disisi lain memang terjadi relasi dagang Amerika Serikat dan dunia Eropa berjatuhan, Ketua G-20 berharap agar krisis global yang terjadi di tahun 2008 ini agar tidak terjadi lagi.

\section{Kondisi perekonomian Indonesia Saat Krisis Global 2008}

Gejolak perekonomian yang semula diakibatkan oleh krisis ekonomi di Amerika Serikat juga kemudian berimbas ke seluruh dunia. Tingkat konsumerisme yang tinggi (propincity to consume) sebahagian besar masyarakat Amerika serikat melebihi batas kemampuan pendapatan dimana masyarakat cenderung menggunakan hutang sebagai penopang utama dalam memenuhi kebutuhan sehari-hari seperti penggunaan kartu kredit untuk belanja kebutuhan primer, sekunder maupun tersier. Sebagai contoh penggunaan kartu kredit untuk perumahan yang berimbas pada ketidakmampuan lembaga keuangan pemberi kredit (kehilangan likuiditas) untuk membayar karena piutang perusahaan kepada kreditur perumahan telah digadaikan ke lembaga pemberi pinjaman. Hal tersebut mengakibatkan bursa saham di Wall Street tak berdaya, banyak perusahaan besar tak mampu bertahan dan membayar hutang-hutang yang bersamaan jatuh tempo seperti Lehman Brothers dan Goldman Sachs. Akibat krisis tersebut daya beli masyarakat Amerika Serikat menurun yang selama ini dikenal sebagai konsumen terbesar atas produk-produk dari seluruh dunia. Menurunnya daya beli masyarakat membuat tingkat volume impor menurun drastis yang tentunya juga mempengaruhi volume ekspor dari negara-negara pemasok penyedia produk yang dibutuhkan oleh industri di Amerika Serikat

Krisis keuangan di Amerika serikat merambah sektor riil dan non keuangan di seluruh dunia termasuk negara-negara berkembang. Indonesia sebagai salah satu negara berkembang juga turut mengalami dampak dalam perekonomian yang terlihat dari beberapa indikator diantaranya: harga saham merosot tajam di bursa BEI, nilai tukar rupiah melemah terhadap dollar US yang sudah menembus angka psikologis, sektor perbankan mengalami kesulitan likuiditas, bahkan pemerintah sulit mencari pinjaman di pasar keuangan (Sugema, 2008).

Dampak lanjutan dari krisis keuangan terjadi pelambatan perekonomian yang dirasakan oleh masyarakat diantaranya pemutusan hubungan kerja (PHK) dalam aktivitas perusahaan. Hal tersebut diambil sebagai bentuk kebijakan perusahaan akibat kondisi perekonomian yang lesu. Setidaknya sampai tahun 2009 Pemerintah menyatakan ada sekitar 57.000 tenaga kerja yang di PHK akibat dari imbas krisis ekonomi 2008-2009 (Republika 24 Juni 2009). Disamping itu menurut (Sihono, 2008), 
harga minyak dunia yang terus mengalami kenaikan menembus angka US \$110 menggoncang stabilitas ekonomi karena synthom dan kenaikan inflasi untuk membiayai subsidi BBM dan listrik bagi masyarakat yang memiliki kebutuhan 1.3 barel per hari nyaris menghabiskan seperempat anggaran APBN.

Selanjutnya hal yang dialami oleh banyak negara termasuk Indonesia adalah tingginya harga komoditas dunia (impor) yang berimbas pada harga komoditas domestik (ekspor) sehingga terjadi krisis pangan yang diperkirakan melanda 36 negara (Kompas, 15 maret 2008). Kondisi tersebut menggambarkan bahwa terjadi peningkatan angka pengangguran sekaligus angka kemiskinan yang dihadapi oleh masyarakat dan beban pengeluaran yang memicu terjadinya inflasi bagi pemerintah sebagai suatu masalah krusial yang perlu dicarikan solusi untuk tidak memperparah kondisi perekonomian secara makro.

Menghadapi hal tersebut pemerintah berupaya melakukan berbagai tindakan untuk mengurangi dampak akibat kondisi ekonomi global terutama bagi kepentingan masyarakat bawah. Daya beli masyarakat turun akibat naiknya harga pangan dan kebutuhan pokok membuat pemerintah mengubah besaran subsidi BBM, listrik serta kebutuhan pokok untuk meringankan beban masyarakat dalam memenuhi kebutuhan dasarnya. Hal tersebut dilakukan dengan merealokasi anggaran APBN dengan menggeser pembiayaan sektor-sektor lain. Revisi dilakukan berulang-ulang untuk tahun anggaran 2009 diturunkan dari 6.7-7.2 \% menjadi 6.4-6.9 \%, bahkan angka tersebut pun akan diturunkan $2 \%$ untuk mengantisipasi terjadinya defisit (Sihono, 2008).

Disisi lain, upaya yang dilakukan terhadap kenaikan harga pangan yang disebabkan karena perubahan iklim, pertambahan populasi kenaikan harga bahan bakar yakni petani melakukan adaptasi terhadap kenaikan harga/permintaan yang diikuti dengan keringanan dan kemudahan mendapatkan kredit, bantuan bibit, ternak dan keterampilan untuk meningkatkan hasil pertanian. Hal tersebut dilakukan untuk meningkatkan persediaan dan kestabilan harga (Sihono, 2008).

Belajar dari pengalam krisis ekonomi 1997-1998 maka pemerintah lebih siap meskipun masih dalam meletakkan tahap fundamental terhadap sektor perekonomian secara makro (neraca pembayaran, perbankan, fiskal, moneter). Penurunan tingkat suku bunga berdampak pada meningkatnya permintaan agregat dan struktur penyaluran kredit $25 \%$ yang pada akhirnya mampu menggerakaan sektor real dan peningkatan pada penerimaan pajak. Untuk menggerakkan sektor real dan konsumsi masyarakat, salah satu instrumen finansial adalah melonggarkan pengucuran kredit produktif (Sihono, 2008).

Selanjutnya penghasilan devisa dari ekspor tidak lagi menggantungkan pada negara-negara maju tetapi lebih kearah menjaga dan melindungi eksistensi pasar domestik dalam negeri agar tidak terdistorsi oleh membanjirnya prduk-produk dari dari negara Asia yang lain dalam bentuk crash program yang mengalihkan ekspor dari negara maju ke negara berkembang.

Menurut (Sihono, 2008) Bank Indonesia (BI) dalam hal ini sebagai perpanjangan tangan dari pemerintah perlu melakukan kebijakan moneter dalam menekan inflasi dalam bentuk mendukung efektivitas transmisi kebijakan moneter melalui jalur suku bunga (menggunakan overnight/suku bunga pasar antar bank) yang diikuti dengan upaya optimalisasi pelaksanaan intervensi valas, akselerasi program untuk memperluas basis instrument pasar finansial. 


\section{Kesimpulan}

Berbagai faktor yang menyebabkan terjadinya krisis ekonomi, baik itu dari faktor eksternal maupun faktor internal. Indonesia memiliki banyak keberuntungan dari resesi ini sehingga efek dari resesi global ini tidak terlalu besar dibanding negara emerging market lainnya karena Indonesia tidak terlalu menggantungkan ekonominya di pangsa ekspor, kedua sektor perbankan maupun sektor finansial tidak terlalu mengalami dampak yang seberat negara kainnya, ketiga bursa yang mengalami penurunan tidak terlalu berpengaruh pada ekonomi Indonesia karena pelaku pasar saham hanyalah 0,5\% dari penduduk Indonesia, dan terakhir Indonesia dapat dikatakan sebagai self sustainability economy karena potensi pasar domestik yang sangat besar sehingga walaupun pasar luar negeri lemah namun pasar domestiknya sudah sangat besar. Akan tetapi meskipun Indonesia memegang keberuntungan diatas, imbas krisis global tersebut pada pengangguran dan kemiskinan tidak dapat sepenuhnya dihindari.

\section{Referensi}

Arum tri utami, renny miryanti, tundjung linggarwati. 2015. "Upaya Diplomasi Indonesia Dalam Forum G20 Untuk Mewujudkan Framework for Strong, Sustainable and Balanced Growth 2008-2012." Jurnal INSIGNIA 2(02): 11-27.

Atmadja, Adwin S. 1999. "Inflasi Di Indonesia: Sumber-Sumber Penyebab Dan Pengendaliannya." Jurnal Akuntansi dan Keuangan 1(1): 54-67.

Faiz, Ihda. 2010. "Ketahanan Kredit Perbankan Syariah Terhadap Krisis Keuangan Global."La_Riba 4(2): 217-37.

Hadi, Didik Kurniawan. 2008. "Dampak Krisis Keuangan Global Bagi Indonesia."

Hidayat, Adrian. 2008. "Integrasi Ekonomi Asia: Solusi Asia Menghadapi Krisis Global 2008." The Winners 9(2): 180.

Nezky, mita. 2013. "Pengaruh Krisis Ekonomi Amerika Serikat Terhadap Bursa Saham Dan Perdagangan Indonesia." Buletin Ekonomi Moneter dan Perbankan 2013: 89-104.

Njoo, Henry L. 2008. "Akar Krisis Global: Amerika." Jurnal Kompetensi Manajmen Bisnis Vol.2 No.: 119-37.

Nur, Baiti. 2020. "Krisis Ekonomi Dan Resesi EkonomI."

Sugema, Iman. 2012. “Krisis Keuangan Global 2008-2009 Dan Implikasinya Pada Perekonomian Indonesia ( 2008-2009 Th Global Financial Crisis and Its Implications on Indonesian Economy )." 17(3): 145-52.

Tarmidi, Lepi T. 1998. "Krisis Moneter Indonesia: Sebab, Dampak, Peran IMF Dan Saran *)." : 1-25.

Teguh, Sihono. 2009. "Dampak Krisis Finansial Amerika Serikat Terhadap Perekonomian AsiA.” Jurnal Ekonomi \& Pendidikan 6 nomor 1: 1-20.

Timur, Asia et al. 2012. "Krisis Keuangan Global Dan Pertumbuhan Ekonomi : Analisa Dari Perekonomian.” Buletin Ekonomi Moneter dan Perbankan 15 NO 2: 37-56.

Sihono, Teguh.2008. Krisis Finansial Amerika Serikat dan Perekonomian Indonesia. Jurnal Ekonomi dan Pendidikan. Volume 5. No.2:181-189

Sugema, Iman. 2012. Krisis keuangan Global 2008-2009 dan Implikasinya pada perekonomian Indonesia. Jurnal Ilmu Pertanian Indonesia (JIPI). Volume 17. No.3: 146-147 